Niniejsza publikacja jest dostępna na licencji Creative Commons. Uznanie autorstwa-Użycie niekomercyjne-Bez utworów zależnych 3.0 Polska. Pewne prawa zastrzeżone na rzecz autora. Zezwala się na wykorzystanie publikacji zgodnie z licencja - pod warunkiem zachowania niniejszej informacji licencyjnej oraz wskazania autora jako właściciela praw do tekstu. Treść licencji jest dostęna na stronie: http://creativecommons.org/licenses/by-nc-nd/3.0/pl/

Lingwistyka Stosowana 20: 5/2016, 31-49

\title{
Agnieszka DĘBSKA
}

Polska Akademia Nauk

\section{Tomasz SOLUCH}

Institute of Sensory Analysis - ISA

\author{
Sylwia SZOSTAKOWSKA
}

Polska Akademia Nauk

\section{Metodologia badań nad przyjmowaniem perspektywy poznawczej podczas dialogu ${ }^{1}$}

\begin{abstract}
:
The methodology of conversational perspective-taking studies.

The goal of the article is to critically analyze the methodology of research on cognitive perspective-taking in the context of dialogue. It will be examined how well the experimental method is suited to the research questions. Furthermore, the available data analysis strategies based on behavioral and eye-tracking sources will be presented. The critics will concern elements of the method associated with the choice of visual stimuli and scenarios of interaction used in the experimental setup. We proposed modifications of the method that may improve experimental approach in the further studies.
\end{abstract}

\section{Wstęp}

Aby zrozumieć, co chciał nam przekazać nasz rozmówca poprzez swoją wypowiedź powinniśmy właściwie zrekonstruować jego intencje komunikacje lub pewien zakres jego przekonań. Musimy zatem przyjąć jego perspektywę poznawczą (zrozumieć, co wie, a czego nie wie nasz interlokutor na pewien temat). To podstawowe pragmatyczne założenie dotyczące interpretacji wypowiedzi stało się przedmiotem badań na gruncie psycholingwistyki (zob. H.H. Clark 1996, 1992). Badania psychologiczne koncentrują się na tym, jak efektywnie osoby dorosłe są w stanie wykorzystać informacje na temat wiedzy rozmówcy w procesie interpretacji wypowiedzi (psychologia komunikacji)? Jakie zdolności poznawcze oraz różnice indywidualne wpływają na efektywne rekon-

${ }^{1}$ Praca wykorzystuje fragmenty nieopublikowanej pracy doktorskiej pierwszego autora, pt. Rekonstruowanie wiedzy i perspektywy poznawczej drugiej osoby w procesie komunikacji. Autor uzyskał środki finansowe na przygotowanie rozprawy doktorskiej z Narodowego Centrum Nauki w ramach finansowania stypendium doktorskiego na podstawie decyzji numer UMO2015/16/T/HS6/00328. 
struowanie perspektywy innych osób (psychologia poznawcza)? I w końcu, jak zdolność do przyjmowania perspektywy zmienia się w ciągu życia człowieka (psychologia rozwojowa)?

Celem niniejszej pracy jest szczegółowe przedstawienie metody eksperymentalnej opierającej się na paradygmacie świata wizualnego (ang. Visual World Paradigm, zob. M.K. Tannehaus $i$ in. 1995), która powstała na potrzeby badania przyjmowania perspektywy poznawczej w czasie dialogu. W pracy opiszemy, w jaki sposób metoda ta została rozwinięta i udoskonalona, oraz przedstawimy problemy związane z zastosowaniem metody jak i zarysujemy perspektywę dalszych badań.

Będziemy koncentrować się na użyciu metody w obszarze psychologii komunikacji. Praca opisuje paradygmat, który początkowo dotyczył jedynie badań z udziałem typowych osób dorosłych. Niewątpliwie jednak metodę można przystosować do badania przyjmowania perspektywy w kontekście rozwojowym oraz klinicznym, co zostanie opisane w ostatniej części pracy. Opisany zostanie również alternatywny sposób badania przyjmowania perspektywy poznawczej poza kontekstem komunikacji językowej (zob. A. Quershi i in. 2010).

\section{1. Źródła badania przyjmowania perspektywy poznawczej w czasie dialogu}

W latach $80 \mathrm{XX}$ w. Herbert H. Clark zaproponował teorię komunikacji opartą na wspólnej wiedzy (ang. common knowledge, common ground, H.H. Clark/ C.R. Marshall 1978, zob. też H.H. Clark 1992, 1996). Wspólna wiedza (lub wspólny grunt) to pojęcie stosowane na określenie zbioru podzielanych przekonań i presupozycji pary rozmówców, które są dodatkowo rozpoznane przez obu rozmówców jako wspólnie podzielane. Nie będzie zatem częścią wspólnego gruntu indywidualna wiedza obu stron (np. że osoba $\mathrm{X}$ wydaje przyjęcie urodzinowe), jeśli obaj rozmówcy sądzą, że tylko oni, ale nie druga osoba, o tym wiedzą (np. zaproszenia zostały wysłane w tajemnicy). Ale jeśli ta informacja pojawi się w trakcie rozmowy, np. rozmówcy omawiają prezent, który chcą wspólnie kupić, lub zostaną zaproszeni przez X w momencie, kiedy są razem, wtedy informacja „X wydaje przyjęcie urodzinowe” staje się częścią ich wspólnej wiedzy.

Jeden ze sposobów operacjonalizacji reguł dotyczących wspólnej wiedzy i przełożenia ich na konkretne procesy psychologiczne zaproponował sam H.H. Clark (H.H. Clark/ T.B. Carlson 1981). Postawił on hipotezę „ograniczonego przeszukiwania” mówiącą, że kiedy odbiorca próbuje zinterpretować przekaz nadawcy, ogranicza się automatycznie do informacji, które są częścią ich wspólnej wiedzy. Jednak, aby zrekonstruować wiedzę rozmówcy i zakres wspólnej wiedzy, należy efektywnie przyjąć jego perspektywę poznawczą.

Hipoteza o ograniczonym przeszukiwaniu oraz natychmiastowym przyjmowaniu perspektywy drugiej osoby zostały poddane w wątpliwość w badaniach B. Keysara i współpracowników (B. Keysar i in. 1998, B. Keysar i in. 2000, B. Keysar i in. 2003). Skupili się oni na badaniu komunikacji w czasie rzeczywistym i na analizie poszczególnych etapów procesu interpretacji wypowiedzi. Analiza szczegółowego przebiegu interpretacji wypowiedzi była możliwa dzięki zastosowaniu pomiaru ruchu oczu z użyciem mobilnego okulografu. 
B. Keysar i współpracownicy (B. Keysar i in. 2000) zaprojektowali grę komunikacyjną (ang. director task), w której badani mieli przesuwać przedmioty zgodnie z poleceniami instruktora (niejawnego pomocnika eksperymentatora). Pomiędzy odbiorcą (badanym) a nadawcą (instruktorem) postawiono szafkę, w której niektóre przegródki były widoczne $\mathrm{z}$ obu stron, a inne zostały zasłonięte $\mathrm{z}$ jednej strony tak, aby tylko odbiorca (badany) mógł zobaczyć, co jest w środku (por. rys. 1).

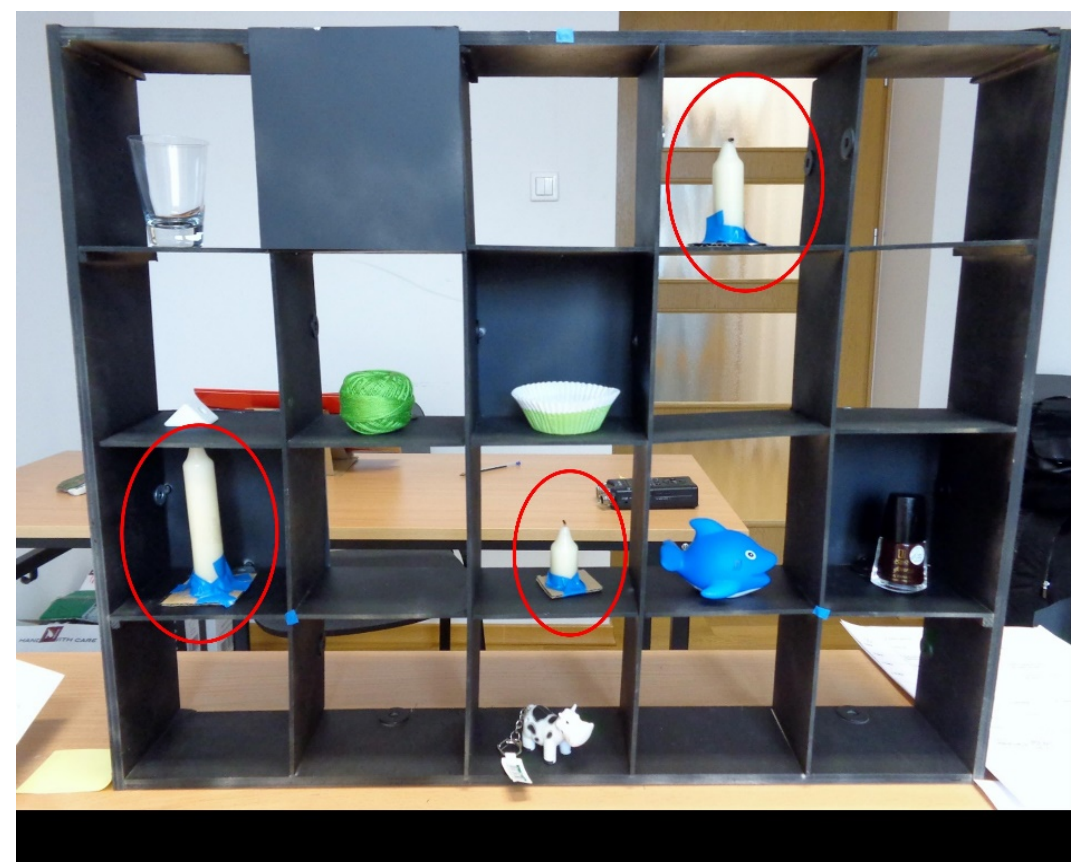

Rysunek 1. Sytuacja eksperymentalna.

Polecenie: „Przesuń dużą świeczkę (...)”.

Przed rozpoczęciem eksperymentu badany był oprowadzany dookoła szafki tak, by przekonał się, że ze strony nadawcy nie można zobaczyć zasłoniętych przedmiotów. Sytuacja została też przedstawiona tak, by było jasne, że nadawca (instruktor) również pełni rolę badanego i nie wie, co jest w zablokowanych przegródkach. Wyniki osób, które domyśliły się, że instruktor jest pomocnikiem eksperymentatora, nie były brane pod uwagę w dalszej analizie. W ten sposób zostało stworzone pole wspólnej perspektywy wizualnej (common ground) składające się z przedmiotów, które osoba badana $\mathrm{i}$ instruktor widzieli wspólnie, oraz prywatny obszar (privileged ground) składający się z przedmiotów widzianych tylko przez badanego. W warunku eksperymentalnym zarówno w polu wspólnym, jak i prywatnym znalazły się przedmioty należące do tej samej kategorii, np. na szafce badany widział trzy świeczki: większą i mniejszą w przestrzeni wspólnej oraz największą w przestrzeni prywatnej (por. rys. 1). Krytyczna instrukcja wypowiadana przez instruktora $\mathrm{w}$ trakcie zadania brzmiała np.: „Przesuń duża świeczkę pod włóczkę". Jeśli badany bierze pod uwagę perspektywę instruktora, powinien zignorować największą świeczkę, gdyż wie, że instruktor nie może się do niej odnosić, i zamiast tego przesunąć świeczkę średnią ze swojej perspektywy, ale 
dużą z pespektywy instruktora. Dzięki mierzeniu ruchów oczu za pomocą okulografu można odpowiedzieć nie tylko na pytanie, jaki przedmiot ostatecznie wybrał badany, ale również, jakie przedmioty rozważał jako potencjalne odniesienia wypowiedzi. W wersji kontrolnej eksperymentu w szafce znajdowały się tylko dwie świeczki: większa i mniejsza, obie we wspólnej przestrzeni; natomiast w przestrzeni prywatnej znajdował się obiekt niebędący konkurentem semantycznym obiektów w przestrzeni wspólnej (np. lakier do paznokci zamiast świeczki, por. rys. 2.).

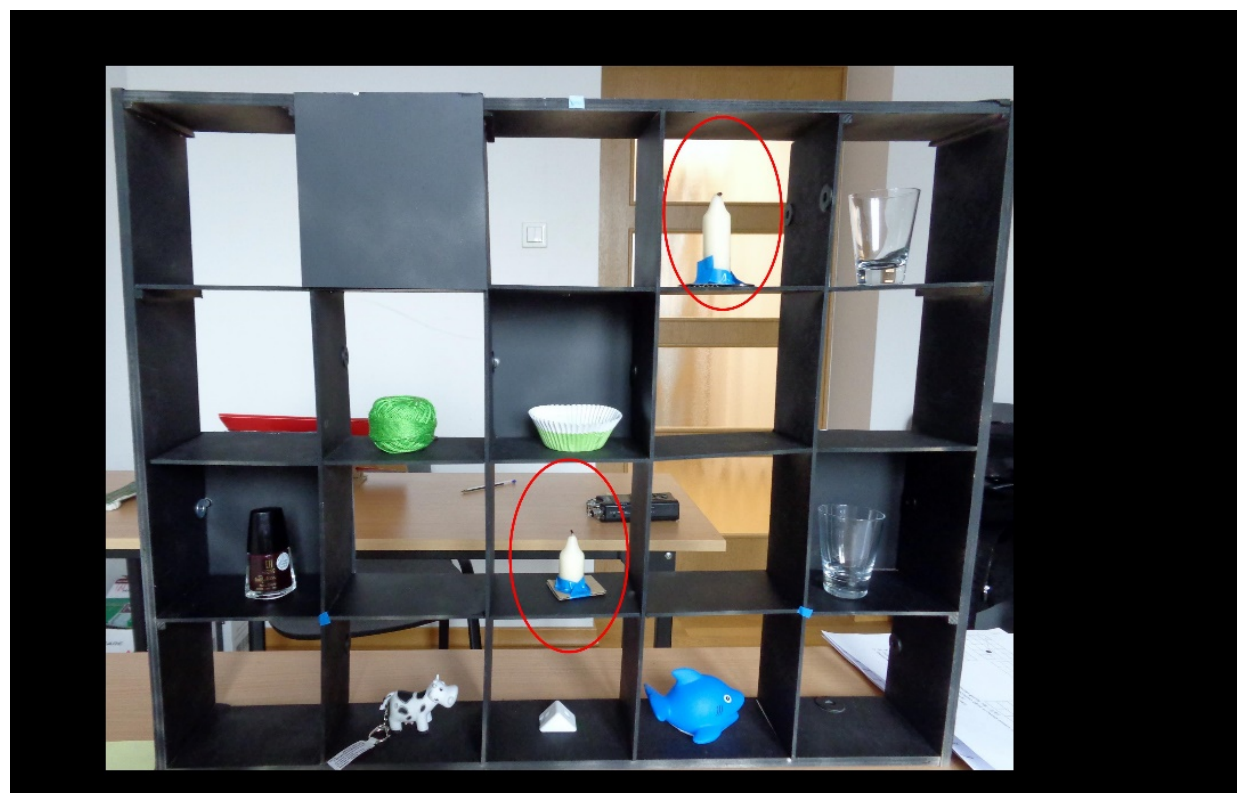

Rysunek 2. Sytuacja kontrolna.

Polecenie: „Przesuń dużą świeczkę (...)”.

Różnica w czasie reakcji jak i w czasie zlokalizowania właściwego przedmiotu na szafce pomiędzy grupą kontrolną a grupą eksperymentalną miała być miarą efektywności w przyjmowaniu perspektywy, tzn. pokazywać, na ile osoba badana skutecznie potrafi zignorować przedmioty prywatne, które nie są częścią wspólnej przestrzeni i o których nie wie nadawca wypowiedzi. Wybór prywatnego przedmiotu, o którym nie wiedział nadawca, uznawano za reakcję egocentryczną (tylko na podstawie własnej perspektywy).

W badaniu B. Keysara i współpracowników (2000) badanym przedstawiono 12 różnych ułożeń przedmiotów, po $6 \mathrm{w}$ warunku kontrolnym i eksperymentalnym (Eksperyment 1, 20 osób badanych) lub 10 ułożeń, po 5 w każdym warunku (Eksperyment 2, 40 osób badanych).

Wyniki okazały się zaskakujące: w warunku eksperymentalnym średnio w 17\% przypadków badani przenosili ukryty przedmiot, a w $6 \%$ przypadków wyciągali po niego rękę i po chwili cofali, by wybrać ostatecznie przedmiot ze wspólnej przestrzeni (Eksperyment 1, B. Keysar i in. 2000). Replikacje tych wyników wykazały wyraźny błąd egocentryczny na poziomie 15\% (przestawianie) i 5\% (sięganie) (B. Keysar i in. 2000, Eksperyment 2). Innymi słowy, każdy badany średnio raz w ciągu całego bada- 
nia przeniósł lub sięgnął po ukryty przedmiot (w przypadku 5 sytuacji w warunku eksperymentalnym).

Analiza danych okulograficznych wskazała, że badani rozważali ukryte obiekty jako potencjalne odniesienie wypowiedzi: średni czas pierwszych fiksacji na ukrytym obiekcie był wcześniejszy od czasu pierwszych fiksacji na przedmiocie wspólnym (który należało przełożyć). Co więcej, czas ostatnich fiksacji na przedmiocie wspólnym po usłyszeniu polecenia, a przed sięgnięciem po ten przedmiot, był istotnie wydłużony w sytuacji, gdy ukryty obiekt był konkurentem semantycznym, w porównaniu do czasu reakcji w grupie kontrolnej. Świadczy to o tym, że badani rozważali wybór ukrytego przedmiotu, nawet, jeśli ostatecznie go nie wybrali.

Podsumowując, wyniki eksperymentów mogą świadczyć o tym, że, przeciwnie do twierdzeń H.H. Clarka, odbiorca nie ogranicza automatycznie obszaru interpretacji tylko do obszaru wspólnej wiedzy. Autorzy badań (np. B. Keysar i in. 1998, 2000, 2003) twierdzą, że pierwszy etap interpretacji jest zawsze egocentryczny; dopiero na drugim etapie i przy wystarczających zasobach poznawczych dokonuje się korekta interpretacji z egocentrycznej na taką, która uwzględnia perspektywę rozmówcy (H. Shintel/ B. Keysar 2009). Podobne rezultaty uzyskano w analogicznym do opisanego powyżej badaniu (B. Keysar i in. 2003), w którym konkurujące obiekty miały homonimiczne nazwy, mogące odnosić się do dwóch różnych przedmiotów (np. mysz komputerowa i mysz-maskotka). W takiej sytuacji badany po usłyszeniu wieloznacznego polecenia (np. „Podaj mysz.”) potrzebował więcej czasu na jego interpretację. Odbiorca popełniał więcej błędów egocentrycznych nawet w sytuacji, gdy przedmiotkonkurent, o którego istnieniu wiedział tylko on, ukryty był w zamkniętej papierowej torbie. Zatem sama wiedza o obecności tego przedmiotu powodowała rozważanie go jako potencjalne odniesienie wypowiedzi (badany nie musiał go nawet widzieć przed sobą). B. Keysar i współpracownicy wskazują na fakt, że, w przeciwieństwie do egocentrycznej interpretacji, dokonywanie korekty jest czynnością wymagającą zasobów poznawczych. W badaniu S. Lini i współpracowników (2010) pokazano, że lepsza kontrola tendencji egocentrycznej w takim samym zadaniu korelowała pozytywnie $\mathrm{z}$ poziomem pamięci roboczej, zaś spadała wraz z dodatkowym obciążeniem poznawczym.

Zadanie B. Keysara i innych, a także jego wersje komputerowe (np. I. Dumontheil i in. 2010, I.A. Apperly i in. 2010) i wersje alternatywne (np. S. Brown-Schmidt 2009, J.E. Hanna i in. 2003) stały się przydatnym narzędziem do pomiaru stopnia przyjmowania perspektywy poznawczej a także kontroli egocentryzmu dla różnych grup osób badanych. Poniżej przedstawię szczegółowy opis metody, zwracając uwagę na szerszy kontekst metodologiczny. Wymienię podstawowe wskaźniki wykorzystywane podczas pomiaru, związane również z zastosowaniem mobilnego i stacjonarnego okulografu. Na końcu krytycznie analizuje metodę, wskazując na jej ograniczenia oraz zalety w innych badaniach.

\section{Badanie procesów poznawczych podczas komunikacji i współpracy}

Metoda zaprojektowana przez B. Keysara została oparta na bardziej ogólnym paradygmacie badawczym analizującym proces interpretacji w czasie rzeczywistym (on- 
line), który zaproponował M.K. Tanenhaus wraz ze współpracownikami (M.K. Tanenhaus i in. 1995, M.K. Tanenhaus/ J.C. Trueswell 1995). Był to nowatorski sposób badania procesów językowych, który umożliwił śledzenie, jak szczegółowe procesy poznawcze wpływają na interpretację wypowiedzi. Dzięki tej metodzie można badać nie tylko efekty procesu interpretacji, czyli końcowe decyzje, ale sam przebieg procesu, w bardziej naturalnym niż dotychczas kontekście komunikacyjnym. Metoda umożliwia również badanie dialogu i współpracy $\mathrm{z}$ drugą osobą $\mathrm{w}$ świecie fizycznym.

Zgodnie z paradygmatem VWP (Visual World Paradigm) badanemu zostaje zaprezentowany pewien układ przedmiotów (bezpośrednio przed nim lub na ekranie komputera). Zadaniem badanego jest manipulowanie przedmiotami zgodnie z instrukcją. Zarówno ruchy jego ciała, jak i oczu są rejestrowane. Używany jest okulograf mobilny w przypadku, gdy badany ma manipulować prawdziwymi przedmiotami, lub okulograf stacjonarny, gdy przedmioty wyświetlane są na ekranie komputera. M.K. Tanenhaus i współpracownicy (1995) udowodnili, że moment przeniesienia wzroku na dany obiekt jest równoznaczny z potraktowaniem tego przedmiotu jako odniesienia wypowiedzi. Wypowiedzenie nazwy przedmiotu powoduje, że badany z istotnie większym prawdopodobieństwem przeniesie wzrok na konkretny obiekt a pominie inne. Rezultaty te pozwoliły na potwierdzenie dwóch istotnych faktów: badanie ruchu oczu za pomocą okulografu może dać wgląd w przebieg procesu interpretacji wypowiedzi oraz proces interpretacji odbywa się w sposób przyrostowy (incremental). Znaczy to, że, przetwarzając wypowiedź językową, na bieżąco gromadzi się i wykorzystuje dane pozwalające na zlokalizowanie odniesienia (M.A. Tanenhaus/ J.C. Trueswell 1995). Na przykład, na początku wypowiadania słowa „bu...”, gdy potencjalnym odniesieniem jest kilka przedmiotów, w tym burak i butelka, po ok. $200 \mathrm{~ms}$ proporcja fiksacji na obu tych przedmiotach będzie porównywalna i większa niż na innych obiektach. Jednak po wypowiedzeniu całego słowa „burak”, po następnych 200 ms wystąpi znaczna przewaga fiksacji wzroku na buraku a spadnie liczba fiksacji na butelce (oryginalne przykłady: beaker i beetle, w: P.D. Allopenna i in. 1998). Nie tylko informacja fonetyczna i semantyczna, ale także pragmatyczna (np. ułożenie przedmiotów w scenie wizualnej) może zmodyfikować bieżący proces interpretacji. Inny jest przebieg interpretacji zdania „Put the apple on the towel in the box”, jeśli badani widzą przed sobą dwa jabłka, jedno na ręczniku, drugie na serwetce, niż w przypadku, gdy słyszą polecenie „Put the apple that's on the towel in the box" (M. Spivey i in. 2002).

W badaniu interpretacji i procesów poznawczych w czasie dialogu wykorzystuje się Paradygmat Świata Wizualnego (VWP), stosując go w grze komunikacyjnej między nadawcą a odbiorcą wypowiedzi. W takich grach badany zazwyczaj pełni rolę osoby manipulującej przedmiotami (matcher) zgodnie z instrukcją od nadawcy (director), który przeważnie jest jawnym bądź ukrytym pomocnikiem eksperymentatora $\mathrm{i}$ wydaje polecenia zgodnie $\mathrm{z}$ rozpisanym wcześniej skryptem. Zwykle przestawianie przedmiotów wiąże się $\mathrm{z}$ określonym celem, np. odbiorca ma poukładać je na szafce tak, by ostateczne ustawienie przedmiotów było identyczne ze zdjęciem lub schematem, które dostał nadawca. W przypadku zadania w formie komputerowej, scena wizualna przedstawiona jest na ekranie i polecenia wydaje albo nagrany głos (np. D.J. Barr 2008), albo awatar symbolizujący nadawcę polecenia (I. Dumontheil i in. 2010). Z 
reguły w przypadku badań komputerowych dba się o urealnienie postaci nadawcy. W tym celu badany może zostać na przykład poinformowany, że usłyszy głos osoby siedzącej w innym pokoju (D.J. Barr 2008). Istnieje również bardziej ekologiczna odmiana tego paradygmatu, w której badany podaje drugiej osobie (instruktorowi) przedmioty, które są jej potrzebne, by wykonać jakąś czynność. Na przykład badany jest pomocnikiem kuchennym, więc podaje naczynia i składniki na prośbę kucharza-nadawcy (J.E. Hanna/ M.K. Tanenhaus 2004).

Wiele elementów tej metody ma wpływ na uzyskane wyniki - przede wszystkim to, czy pomocnik eksperymentatora ma przygotowany wcześniej skrypt, czy też dialog i współpraca są spontaniczne (A.K. Kuhlen/ S.E. Brennan 2012), a także to, czy zadanie jest przedstawione w sposób bardziej lub mniej przypominający naturalną sytuację współpracy (J.E. Hanna i in. 2003). W tym miejscu warto przytoczyć analizę A.K. Kuhlen/ S.E. Brennan (2012), zgodnie z którą naturalność i spontaniczność dialogu może mieć wpływ na efekty związane z projektowaniem wypowiedzi lub interpretowaniem jej z uwzględnieniem perspektywy rozmówcy. Badaczki wskazują na cztery zagrożenia $\mathrm{w}$ badaniu dialogu, $\mathrm{w}$ momencie, gdy tylko jeden rozmówca jest faktycznym badanym, a drugi jest pomocnikiem eksperymentatora, które mogą spowodować nietypowe zachowania (por. przegląd badań w S.E. Brennan/ A.K. Kuhlen 2012). Są nimi: po pierwsze, użycie skryptów komunikacji, które czasem mogą nie wpasować się naturalnie $\mathrm{w}$ dialog, zaburzając typowe dla dialogu mechanizmy; po drugie, zbyt duża wiedza pomocnika mogąca wpływać na jego niewłaściwe reakcje zwrotne; po trzecie, pomocnik może być zbyt dobrze poinformowany o celu eksperymentu i nieświadomie wpływać na badanych tak, by uzyskać zamierzony przez eksperymentatora efekt; wreszcie po czwarte, badany może mieć podejrzenia, że rzekomy rozmówca jest tak naprawdę współpracownikiem eksperymentatora. Każde niebezpieczeństwo jest do pewnego stopnia kontrolowane w badaniach nad przyjmowaniem perspektywy poznawczej w czasie dialogu (m.in. osobno analizuje się wyniki osób badanych, które przyznały, że podejrzewały rozmówcę o bycie pomocnikiem eksperymentatora, np. B. Keysar 2000). Nadal jednak większość badań przyjmowania perspektywy w czasie dialogu opiera się na skryptach komunikacyjnych, ponieważ istotne jest, by podczas dialogu padły określone słowa, skoro to właśnie reakcja na nie jest przedmiotem badania.

\section{Wskaźniki użyte w zadaniu B. Keysara i innych.}

Paradygmat Świata Wizualnego daje możliwość mierzenia, na jakie konkretnie przedmioty badany patrzył zaraz po usłyszeniu wieloznacznej nazwy - a więc jakie przedmioty rozważał on jako potencjalne odniesienie wypowiedzi. Dzięki temu eksperymentator ma dostęp nie tylko do wyniku procesu interpretacji (którym jest sięgnięcie po określony przedmiot po usłyszeniu jego nazwy), ale także do przebiegu procesu interpretacji (badany może patrzeć na jakiś przedmiot, ale ostatecznie go nie wybrać).

Podstawowym celem zadania komunikacyjnego B. Keysara i innych jest porównanie reakcji osoby badanej w dwóch sytuacjach: gdy osoba badana słyszy polecenie, które może odnosić się do przedmiotu znajdującego się zarówno w przestrzeni prywatnej, jak i w przestrzeni wspólnej oraz gdy osoba badana słyszy polecenie, które odnosi 
się tylko do przedmiotu w przestrzeni wspólnej. To, czy i jak efektywnie osoba badana weźmie pod uwagę, że nadawca nie wie o przedmiotach w prywatnej przestrzeni, jest miarą zdolności do przyjmowania perspektywy poznawczej i kontroli egocentryzmu. W przypadku szczegółowej analizy samego procesu interpretacji wypowiedzi (czyli tego, jaki przedmiot jest właściwym odniesieniem wypowiedzi), celem badania jest określenie, jak efektywnie użyte są wskazówki dotyczące perspektywy nadawcy wypowiedzi w procesie interpretacji (lokalizowania odniesienia przedmiotowego).

Można więc powiedzieć, że badanie czasu reakcji i błędów egocentrycznych bardziej oddaje efekt procesu interpretacji (wyboru właściwego lub niewłaściwego przedmiotu), natomiast wskaźniki okulograficzne oddają przebieg procesu interpretacji (np. jak często osoba badana patrzyła na przedmiot w prywatnej przestrzeni zanim podjęła decyzję o wyborze przedmiotu we wspólnej przestrzeni).

Aby móc opisać podstawowe wskaźniki w zadaniu komunikacyjnym, należy najpierw przedstawić jego podstawową strukturę, wspólną dla opisywanego już oryginalnego zadania B. Keysara, a także dla wersji komputerowych, gdzie obraz szafki i instruktora przeniesiony jest na ekran komputera czy alternatywnych (np. S. BrownSchmidt 2009, A. Dębska/ J. Rączaszek-Leonardi 2016), gdzie badany nie widzi szafki, ale przestrzeń podzieloną w inny sposób. Podczas zadania badany ma do czynienia z dwoma rodzajami sytuacji.

W sytuacji jednoznacznej osoba badana słyszy polecenie: „Przesuń świeczkę...” i widzi we wspólnej przestrzeni jedną świeczkę, która jest właściwym odniesieniem wypowiedzi (nazywanym też przedmiotem docelowym, targetem). W literaturze (od B. Keysar i in. 2000) taka sytuacja nazwana jest warunkiem kontrolnym.

W sytuacji wieloznacznej osoba badana (odbiorca) słyszy: „Przesuń świeczkę ...”, ale widzi dwie świeczki: jedną znajdującą się we wspólnej przestrzeni między odbiorcą a nadawcą wypowiedzi oraz drugą, o której wie tylko odbiorca. Jest to sytuacja nazywana warunkiem eksperymentalnym. Na potrzeby przykładu załóżmy, że są to dwie identycznie wyglądające świeczki, chociaż w klasycznych zadaniach komunikacyjnych sytuacja jest bardziej skomplikowana (przedmioty mogą różnić się np. wielkością).

Osoba badana (odbiorca) ma do rozwiązania tzw. konflikt odniesienia (reference resolution, zob. J.E. Hanna i in. 2003), który polega na tym, że opis przedmiotu w sensie semantycznym może odnosić się do obu świeczek: świeczki w prywatnej przestrzeni oraz świeczki we wspólnej przestrzeni. Natomiast w sensie pragmatycznym wypowiedź odnosi się do „wspólnej” świeczki, bo taka jest intencja nadawcy wypowiedzi. Dlatego na konflikt odniesienia składają się tak naprawdę dwa konflikty. Pierwszy z nich jest semantyczny i polega na konieczności wyboru przedmiotu najlepiej pasującego do opisu. W przypadku, gdy dwa przedmioty są identyczne, jest to konflikt nierozstrzygalny bez pozyskania dalszych informacji. Drugim jest konflikt perspektyw oparty na konieczności zastosowania informacji o tym, że druga osoba nie wie o jednym z przedmiotów, więc należy go wykluczyć, jako właściwe odniesienie w procesie interpretacji wypowiedzi.

$\mathrm{Z}$ powodu połączenia dwóch rodzajów konfliktów w jednym zadaniu badanie zdolności do przyjmowania perspektywy w procesie komunikacji jest specyficznym sposobem pomiaru efektywności w przyjmowaniu perspektywy innej osoby. Zawsze 
uzyskuje się informację o zastosowaniu zdolności do przyjmowania perspektywy w kontekście przebiegu procesu interpretacji wypowiedzi. $Z$ tego też powodu poznawcze aspekty przyjmowania perspektywy poznawczej drugiej osoby bada się za pomocą różnych zadań, niekoniecznie związanych z przetwarzaniem wypowiedzi podczas dialogu (np. A. Quershi i in. 2010). Z drugiej strony metoda zadania komunikacyjnego dostarcza wielu informacji na temat tego, jak przebiega proces interpretacji wypowiedzi, w którym interpretator musi wykorzystać informacje z wielu źródeł i rozstrzygnąć, jak rozwiązać konflikty semantyczny i pragmatyczny podczas interpretacji. Zatem wynik badań z użyciem takiej metody będzie cenny zarówno dla psychologów poznawczych, jak i dla psychologów języka i komunikacji.

Do pomiaru tego, jak efektywnie badany jest w stanie rozwiązać konflikt odniesienia za pomocą informacji dotyczących perspektywy innej osoby, używa się trzech rodzajów wskaźników (poniżej będę się opierać na literaturze przedmiotu, m. in. B. Keysar i in. 2000, 2003, I.A. Apperly i in. 2010, S. Lini in. 2010, S. Brown-Schmidt 2009, 2012, M.K. Tanenahus i in. 2003, J.E. Hanna/ M.K. Tannehaus 2004, J.J. Wangi i in. 2015).

Pierwszy rodzaj wskaźnika przyjmowania perspektywy w czasie komunikacji to czas reakcji. Czas reakcji mierzony jest od momentu wypowiedzenia przez nadawcę kluczowej nazwy (np. Przesuń świeczkę...”) do momentu wyboru przedmiotu kursorem myszy na ekranie komputera, albo przez dotknięcie przedmiotu na szafce, jeśli eksperyment ma miejsce w świecie rzeczywistym. $Z$ analizy wykluczane są błędne próby, tzn. takie, w których badany przestawił niewłaściwy przedmiot. Standardowo oczekuje się dłuższego czas reakcji w warunku eksperymentalnym względem kontrolnego. Ten wydłużony czas reakcji interpretuje się zwykle jako czas rozwiązywania konfliktu perspektywy. Im dłuższy czas, tym większy koszt poznawczy tego procesu dla danej osoby.

Druga grupa wskaźników przyjmowania perspektywy w czasie komunikacji to liczba i rodzaj wyraźnych błędów egocentrycznych. Wyraźne błędy egocentryczne to takie, które wskazują, że osoba badana wybrała, lub jawnie rozważała jako właściwe, odniesienie wypowiedzi ukryty przedmiot (przedmiot w prywatnej przestrzeni). W literaturze można spotkać dwa rodzaje takich błędów (od: B. Keysar i in. 2000). Są to: przestawienie ukrytego przedmiotu na wskazane miejsce (w zadaniach komputerowych i fizycznych) oraz wyciągnięcie ręki po ukryty przedmiot i dotknięcie go, a następnie cofnięcie ręki (w zadaniach fizycznych, choć odpowiednikiem komputerowym mógłby być pomiar trajektorii ruchu myszy komputerowej, zob. np. N.D. Duran/ R. Dale 2014). Nieanalizowanym do tej pory rodzajem wyraźnego błędu egocentrycznego są reakcje językowe świadczące o konflikcie egocentrycznym. Przykładem może być m. in. dopytanie nadawcy, ,którą dużą świeczkę” ma na myśli lub pytanie: „ta z dołu, czy ta z góry?".

Trzecia grupa wskaźników przyjmowania perspektywy to wskaźniki związane z przebiegiem procesu interpretacji, mierzone za pomocą okulografu. Przede wszystkim bada się przebieg procesu interpretacji w zdefiniowanym oknie czasowym: od momentu wypowiedzenia krytycznej nazwy do momentu wyboru przedmiotu, zarówno na 
ekranie komputera (za pomocą stacjonarnego okulografu), jak i w świecie fizycznym (za pomocą mobilnego okulografu). W szczególności bada się:

1. Czas od momentu wypowiedzenia krytycznej nazwy do momentu rozpoczęcia pierwszych fiksacji na przedmiocie docelowym, będacym właściwym odniesieniem wypowiedzi.

Ten wskaźnik mówi o tym, jak szybko badany lokalizuje przedmiot docelowy i zaczyna rozważać go, jako odniesienie wypowiedzi. Przewiduje się, że czas pierwszych fiksacji na obiekcie docelowym będzie późniejszy w warunku eksperymentalnym niż kontrolnym.

2. Czas od momentu wypowiedzenia krytycznej nawy do momentu pojawienia się ostatnich fiksacji na przedmiocie docelowym przed wybraniem go.

Ten wskaźnik powinien dawać podobne informacje jak i wskaźnik czasu reakcji, to znaczy, na ile istnienie konkurenta semantycznego, ale leżącego w prywatnej przestrzeni, spowodowało wydłużenie czasu interpretacji (zakończonego wyborem właściwego odniesienia). Konkurent semantyczny właściwego odniesienia nazwany jest też dystraktorem, ponieważ „odciąga” uwagę od właściwego przedmiotu i tym samym utrudnia jego wybór. Przewiduje się, że czas ostatnich fiksacji na obiekcie docelowym będzie późniejszy w warunku eksperymentalnym niż kontrolnym.

\section{3. Średnia liczbę fiksacji na obszarze zajmowanym przez konkurenta semantycz- nego.}

Ten wskaźnik mówi, jak często osoby badane zwracają uwagę na konkurenta semantycznego w warunku eksperymentalnym, czyli na ile rozważają ten przedmiot jako możliwe odniesienie wypowiedzi w oknie czasowym pomiędzy usłyszeniem krytycznej nazwy a wybraniem przedmiotu. Średnią liczbę fiksacji na dystraktorze w warunku eksperymentalnym porównuje się do średniej liczby fiksacji na ten sam obszar w warunku kontrolnym, gdy w danym obszarze nie ma przedmiotu, który odpowiada opisowi. Warunek kontrolny traktuje się jako bazowy punkt odniesienia.

W badaniu J.J. Wang (2015) zaproponowano również, by śledzić kierunek spojrzenia osób badanych przed usłyszeniem krytycznego polecenia, a w szczególności w tzw. czasie inspekcji. Czas inspekcji to początkowy moment zadania, trwający 4-5 sekund, od momentu zobaczenia przez osoby badane przedmiotów, do których będą się odnosiły polecenia (długość czasu inspekcji była wybrana arbitralnie). W tym czasie można się spodziewać, że badany będzie przygotowywał się do wykonania zadania i śledził przedmioty zarówno w prywatnym, jak i we wspólnym obszarze. Dzięki pomiarowi fiksacji w czasie inspekcji można stwierdzić, np. czy badani skupiają uwagę najpierw (na obszarze wspólnym czy prywatnym) i czas na jaki się na nim zatrzymują - czyli który z tych obszarów uznają za bardziej relewantny w procesie komunikacji.

Sposoby operacjonalizacji wyżej opisanych wskaźników będą się różnić w zależności od konkretnego zadania komunikacyjnego, np. w zależności od tego, czy zadanie jest wykonywane przez komputer, czy też w świecie fizycznym. Poniżej znajduje się wykres przedstawiający kolejne punkty czasowe charakterystyczne dla zachowania odbiorcy-badanego po usłyszeniu polecenia przez nadawcę. Moment od wypowiedzenia krytycznej nazwy po sięgniecie po przedmiot jest określany jako czas reakcji. 


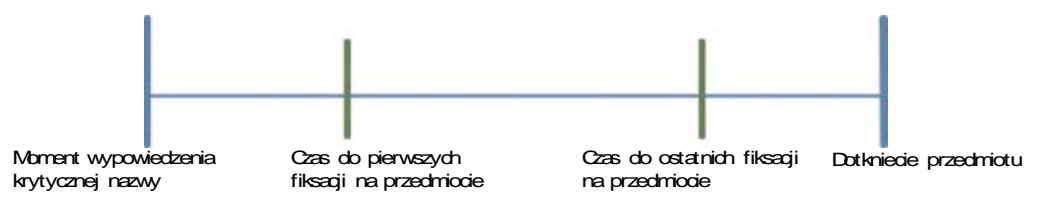

Wykres 1. Linia czasowa standardowo analizowana w zadaniu B. Keysara i innych.

\section{Krytyczna analiza zadania B. Keysara i innych.}

Celem tej części pracy jest omówienie kontrowersyjnych metodologicznie elementów przedstawionego powyżej zadania. Zwrócę uwagę przede wszystkim na te aspekty zadania, które mogą wpływać na obserwowaną liczbę błędów i zaobserwowanych reakcji egocentrycznych w eksperymentach. W pierwszej kolejności opiszę zarzut dotyczący tendencyjnego doboru przedmiotów użytych w zadaniu. Następnie skupię się na niejednoznacznej instrukcji i celach zadania w sytuacji eksperymentalnej.

\section{Bodźce użyte w zadaniu}

Podstawowa krytyka zadania B. Keysara dotyczy faktu, że przedmioty w prywatnej przestrzeni, które miały być ignorowane przez uczestników badania, były zawsze najlepszym odniesieniem danej wypowiedzi pod względem wyrazistości wizualnej lub typowości semantycznej. Na przykład, w reakcji na polecenie instruktora: „Przesuń małą świeczkę..." w momencie, kiedy na szafce znajdują się trzy świeczki: największa, średnia i najmniejsza, oczekiwano, że badany zignoruje najmniejszą świeczkę, którą widzi tylko on, i przesunie średnią pod względem wielkości świeczkę, którą widzi wspólnie z nadawcą wypowiedzi. Podobnie na polecenie: „Podaj taśmę.” (B. Keysar 2003), zgodnie z oczekiwaniami, badany powinien zignorować ukrytą taśmę klejącą (scotch tape) i wybrać taśmę magnetofonową (casette tape), mimo że nie kontrolowano, czy taśma klejąca nie jest bardziej typowym lub częściej używanym odniesieniem słowa „taśma” niż taśma magnetofonowa.

Zatem krytyka dotyczy faktu, iż osoba badana, słysząc wieloznaczne polecenie i widząc dwa przedmioty: jeden, o którym wie tylko ona, ale który bardzo dobrze pasuje też do opisu, oraz drugi, wspólny z nadawcą, ale trochę gorzej pasujący do opisu, musiała rozwiązać dwa rodzaje konfliktu - konflikt semantyczny (ignorowania najlepiej pasującego odniesienia) i konflikt perspektyw (ignorowania przedmiotu niedostępnego dla nadawcy). Można przewidywać, że oba te konflikty niezależnie od siebie (lub wchodząc $w$ interakcję) powodowały wydłużenie czasu reakcji i tendencje egocentryczne. Tę interpretację (przedstawioną w: J.E. Hanna i in. (2003), S. Brown-Schmidt/ J.E. Hanna (2011), ale także rozwiniętą przez autorów niniejszej pracy (A. Dębska/ J. Rączaszek-Leonardi 2016, A. Dębska i in. w przygotowaniu) potwierdzają wyniki badań J.E. Hanny i współpracowników (2003), wedle których rozmówcy potrafili ograniczyć zakres interpretacji do wspólnego gruntu szybko i efektywnie, gdy przedmioty użyte w zadaniu były odpowiednio dobrane.

W badaniu J.E. Hanny i współpracowników (2003), przeprowadzonym w analogicznym do keysarowskiego schemacie eksperymentalnym, rozmówcy grali w grę 
komunikacyjną, która polegała na przesuwaniu figur geometrycznych po tablicach. Każdy z rozmówców miał przed sobą swoją tablicę, a nadawca-instruktor był jednocześnie współpracownikiem eksperymentatora. Pośród różnych figur geometrycznych znajdował się ,sekretny obiekt”. Badany został poinformowany, że tylko on wie o „sekretnym obiekcie”. Autorzy badania przeanalizowali czas poświęcony na fiksacje na sekretnym obiekcie i na odpowiadającym mu obiekcie wspólnym (np. na ,sekretnym” trójkącie i identycznym z nim „wspólnym” trójkącie) po usłyszeniu krytycznej instrukcji: „Połóż trójkąt na kwadracie”. Badani rozpoczęli fiksację na wspólnym trójkącie natychmiast po usłyszeniu instrukcji (ok. $200 \mathrm{~ms}$ ). Badani faktycznie doświadczyli interferencji ze strony „sekretnego” trójkąta - patrzyli na niego częściej niż na inne obiekty na tablicy. To znaczyłoby, że traktowali go przez pewien czas (ok. 400 kolejnych ms) jako bardziej prawdopodobne odniesienie wypowiedzi, niż inne przedmioty, ale istotnie mniej prawdopodobne, niż przedmiot wspólny. Nie wystąpił natomiast wyraźny etap egocentryczny postulowany przez B. Keysara, w którym badani na równi rozważaliby jako odniesienie zarówno sekretny, jak i wspólny obiekt. W tym badaniu informacje na temat wspólnego gruntu natychmiast ograniczyły możliwy konflikt odniesienia. Ważne jest to, że w badaniu przedmiot „prywatny” i przedmiot „wspólny” wyglądały identycznie, zatem badany nie musiał rozwiązywać trudnego konfliktu semantycznego, polegającego na zignorowaniu przedmiotu najlepiej pasującego do opisu.

Ponadto badanie A. Dębskiej/ J. Rączaszek-Leonardi (2016) pokazało, że koszt semantyczny wykonania zadania (wynikający z konieczności ignorowania najbardziej wyrazistych pod względem opisu lub najbardziej typowych przedmiotów) jest niezależny od kosztów rozwiązywania konfliktu perspektyw i pojawia się zarówno w zadaniu przyjmowania perspektywy jak i w analogicznym zadaniu poznawczym, niezwiązanym z komunikacją.

\section{Niejasna rola ,prywatnych” przedmiotów w zadaniu}

W klasycznym zadaniu B. Keysara (por. szczególnie B. Keysar i in. 2000) badany oraz współpracownik eksperymentatora (grający rolę drugiej osoby badanej) byli rzekomo losowo przydzielani do roli nadawcy instrukcji i odbiorcy poleceń. Badany zawsze pełnił rolę odbiorcy poleceń, a współpracownik eksperymentatora zawsze wydawał instrukcje co do przestawiania przedmiotów na szafkach. Zadanie zostało przedstawione jako gra komunikacyjna, w której należało wspólnie przeorganizować półkę $\mathrm{z}$ przedmiotami. Instruktor dostawał zdjęcia przedstawiające docelowe ułożenie przedmiotów na szafce. Miał formułować polecenia tak, by osoba badana ułożyła przedmioty w sposób odpowiadający temu, co widział na fotografii (w rzeczywistości instruktor wypowiadał zdania według skryptu). Szafka na zdjęciach również miała zablokowane półki, podobnie jak szafka w rzeczywistości. W czasie próby badani jeden raz zamieniali się rolami z instruktorem. B. Keysar (2000) w opisie metody nie precyzuje, czy badani przechodzili na miejsce eksperymentatora i widzieli szafkę z jego punktu widzenia, czy tylko wydawali polecenia). Dodatkowo badani zostali poinformowani, że „utrudniono zadanie, umieszczając przedmioty na zablokowanych półkach” (B. Keysar i in. 2000: 34), a także, że instruktor otrzymał zdjęcia przedstawiające lustrzane odbicie ich widoku szafki. W konsekwencji w trakcie zadania instruktor popełniał okazjo- 
nalnie błędy związane z myleniem prawej i lewej strony szafki. Na końcu zadania proszono badanych by zgadli, czy instruktor mógł być pomocnikiem eksperymentatora (dwie na 40 osób badanych w Eksperymencie 2 (B. Keysar i in. 2000) zgadło, że mogło tak być, jednak ich wyniki nie odbiegały od ogólnego wzorca reakcji).

Mimo bardzo prostej instrukcji, jaką otrzymują w tym zadaniu osoby badane (można ją zrekonstruować jako: ,przesuwaj przedmioty zgodnie z poleceniem instruktora, by doprowadzić przedmioty na szafce do właściwego ułożenia", niestety B. Keysar (2000) nie podaje dosłownego zapisu instrukcji), wybór właściwej strategii postępowania nie jest $\mathrm{w}$ tym wypadku jednoznaczny.

Po pierwsze, badany może nie być pewny, jaką rolę odgrywają w całym zadaniu ukryte przedmioty. Innymi słowy - czy te przedmioty są częścią zadania i mają być brane pod uwagę przez badanego, czy też są one poza zestawem przedmiotów biorących udział w zadaniu.

Po drugie, zasadniczym problemem jest to, że jako poprawną reakcję w zadaniu określa się jedynie tę opartą na zinterpretowaniu nazwy przedmiotu jako nazwy indywidualnej, a nie ogólnej. To znaczy, jako takiej nazwy, dla której desygnatem (odniesieniem nazwy) jest pewien konkretny przedmiot, który nadawca miał na myśli, a nie jakikolwiek przedmiot pasujący do opisu. Badany mogą nie być pewni, czy w docelowym ułożeniu przedmiotów liczy się ich wygląd (a więc każda mała świeczka spełni swoje zadanie), czy też muszą to być konkretne, indywidualne przedmioty. Zatem w czasie zadania badany musiał nie tylko zrozumieć, że nadawca nie wie o pewnych przedmiotach, ale że rolą badanego jest przesuwanie przedmiotów, które „ma na myśli" nadawca, a nie dowolnych pasujących do opisu. Co więcej, pomyłka może nie zostać skorygowana $\mathrm{w}$ trakcie eksperymentu ponieważ, w klasycznym zadaniu B. Keysara i in., instruktor nie daje informacji zwrotnej gdy osoba badana popełnia błąd egocentryczny. Czyli w sytuacji, gdy osoba badana przestawi ukryty przedmiot, nie jest ona poprawiana przez instruktora. Jest to niezgodne $\mathrm{z}$ pragmatyką komunikacji i współpracy, ponieważ badani mogą oczekiwać, że w przypadku błędnego przestawienia przedmiotu instruktor zauważy i skoryguje ich pomyłkę. W tym przypadku w osobach badanych wzmacniane jest przekonanie o poprawności zachowania, co może skutkować powtarzaniem błędu w kolejnych turach ustawiania przedmiotów.

Przy okazji warto zauważyć, ze strategia ignorowania przedmiotów, o których nie wie partner $\mathrm{w}$ interakcji, nie jest uniwersalna, a dotyczy tylko pewnych rodzajów zadań. Można sobie wyobrazić sytuacje, w których warto wziąć pod uwagę, że druga osoba nie mówi o pewnych przedmiotach, ale mówiłaby o nich, gdyby o nich wiedziała. Na przykład, jeśli dwie osoby współpracują, by osiągnąć wspólny cel, i jedno z narzędzi (np. śrubokręt 1), o którym wie tylko jedna z osób, jest bardziej przydatne do ukończenia prac niż drugie narzędzie, o którym wiedzą obie osoby (np. śrubokręt 2). Wtedy, ze względu na wspólny cel, bardziej racjonalnym zachowaniem wydaje się podanie narzędzia, które lepiej pasuje do osiągnięcia celu, niż tego, które ma na myśli nadawca polecenia, nieświadomy istnienia innych narzędzi. Trudno uznać w tym przypadku podanie najbardziej optymalnego narzędzia za błąd egocentryczny w procesie interpretacji. To, jakiego rodzaju zachowanie będzie uznane za błąd egocentryczny, a 
jakie przeciwnie - za dowód dostosowania do rozmówcy, będzie wynikać w dużej mierze ze sposobu rozumienia sytuacji komunikacji językowej i współpracy.

$\mathrm{Z}$ analizy tej wynika, że badany może przyjmować perspektywę drugiej osoby $\mathrm{w}$ konkretnej sytuacji komunikacyjnej (nie być egocentrycznym), a jednocześnie nie użyć tej wskazówki w interpretacji wypowiedzi, mimo że jest ona dostępna. Klasyczna instrukcja i kontekst zadania B. Keysara zawierają niejasności co do wiedzy i intencji komunikacyjnych nadawcy oraz roli ukrytych przedmiotów w ukończeniu zadania, co sprawia, że badany może nie mieć pewności, która interpretacja intencji nadawcy jest właściwa dla wykonania zadania.

W badaniu A. Dębskiej i in. (2016, w przygotowaniu) z uwagi na niejasne instrukcje i wątpliwy dobór bodźców w oryginalnych eksperymentach, porównano w jednym zadaniu trzy sytuacje eksperymentalne, jednocześnie przedstawiając badanym zmodyfikowane i jednoznaczne instrukcje ${ }^{2}$.

W pierwszej sytuacji eksperymentalnej obiekt prywatny, który należało zignorować i obiekt wspólny, który należało wybrać wyglądały identycznie jak w klasycznym zadaniu, tzn. obiekt prywatny był bardziej wyrazistym odniesieniem danej nazwy (np. największa świeczka, por. rys. 1). W drugiej sytuacji eksperymentalnej przedmiot prywatny i wspólny równie dobrze pasowały do opisu zawartego w poleceniu, ale różniły się miedzy sobą jedną cechą, np. odcieniem koloru. W trzeciej sytuacji eksperymentalnej przedmiot zarówno prywatny, jak i wspólny wyglądały identycznie (por. rys. 2, kieliszki). Żaden z nich nie był zatem bardziej wyrazisty percepcyjnie. Wyniki badania potwierdziły, ze największy konflikt egocentryczny, mierzony czasem reakcji i ilością błędów egocentrycznych, wystąpił, gdy koszt semantyczny ignorowania przedmiotu był największy (a wiec w pierwszej sytuacji eksperymentalnej). Kontrola egocentryzmu była istotnie łatwiejsza w sytuacji, gdy oba przedmioty, prywatny i wspólny, wyglądały tak samo.

Zatem dobór instrukcji jak i bodźców może w dużym stopniu modyfikować ostateczne wyniki badania. Jeśli badacz decyduje się na użycie opisywanej metody powinien każdorazowo analizować czy wybrany zestaw bodźców, instrukcje i schemat badawczy są dostosowane do celów badania.

\section{Przyszlość badań nad przyjmowaniem perspektywy poznawczej}

$\mathrm{W}$ jakim stopniu metoda stworzona przez $\mathrm{B}$. Keysara $\mathrm{i}$ innych jest przydatną miarą efektywności w przyjmowaniu perspektywy rozmówcy? W pierwszej kolejności opiszę zalety metody oraz możliwości jej wykorzystania w badaniach eksperymentalnych, następnie przedstawię zagrożenia związane z jej używaniem oraz opiszę zadanie alternatywne.

Przede wszystkim, zadanie ,z szafką" jest stosunkowo wysoko ekologicznym sposobem badań nad współpraca z drugim człowiekiem. Szczególnie dotyczy to zadań w rzeczywistej przestrzeni fizycznej. Po pierwsze, kontekst komunikacji jest naturalnym kontekstem, w którym ludzie uczą się przyjmować i zwracać uwagę na swoja perspek-

\footnotetext{
${ }^{2}$ Dokładny opis instrukcji i dokonanych modyfikacji zawarty jest w pracy A. Dębska (2016: 76-80) (nieopublikowana praca doktorska).
} 
tywę. Po drugie, zadanie wprowadza intuicyjne i widoczne rozróżnienie dla dwóch perspektyw: wspólnej i prywatnej. Nie wymaga dodatkowego procesu, jakim byłoby zapamiętywanie, jaka część pola widzenia jest wspólna a jaka nie, w przeciwieństwie do zadań komputerowych opartych na idei badania z szafką, gdzie zaznacza się tylko kolorami tła, które przedmioty są ,wspólne” a które „prywatne” (zob. np. S. BrownSchmidt 2009). Wymaga to jednak od badanego zapamiętania dodatkowych informacji w trakcie zadania.

Zadanie B. Keysara przez swoja ekologiczność stanowi bardzo dobrą alternatywę dla werbalnych zadań mierzących tzw. teorię umysłu, a więc zdolność do rozumowania o stanach mentalnych innych osób. W dużej mierze zadania te (w wersji dla osób dorosłych) opierają się na ocenie, jak zachowają się bohaterowie historyjek, które ogląda lub czyta osoba badana (np. T. German/ J.A. Hehman 2006, S.A.J. Birch/ P. Bloom 2007, P. Mitchelli in. 2006). Wydaje się, że rozwiązanie problemu różnicy perspektyw w trakcie rzeczywistej interakcji daje nam lepszy wgląd w procesy poznawcze towarzyszące zachowaniem społecznym niż efektywność mierzona poprzez wyobrażenie sobie opisanej lub narysowanej historii.

Metoda B. Keysara i in. zaczęła być używana również do badania innych grup niż typowe osoby dorosłe. Przede wszystkim okazała się przydatna w badaniu rozwoju kontroli egocentryzmu w grupach dzieci i nastolatków (J.J. Wangi in. w druku, I. Dumontheil i in. 2010, N. Epley i in. 2004, I. Symeonidou 2016). Jest wykorzystywana w badaniach grup klinicznych, obecnie w grupach osób ze spektrum autyzmu, które wykazują zaburzenia społeczne i językowe, $\mathrm{m}$ in. związane $\mathrm{z}$ ograniczeniami w przyjmowaniu perspektywy innych (I. Santiesteban 2015, S. Begeer i in. 2010). Istnieją również badania porównujące grupy osób z tendencjami autystycznymi i schizofrenicznymi w wykonaniu zadania (A. Abu-Akel i in. 2015). To samo zadanie było też używane w badaniach neuropsychologicznych (np. I. Dumontheil i in. 2010, I. Satnestieban 2012) dla ustalenia mózgowego podłoża odpowiedzialnego za przyjmowanie perspektywy rozmówcy w trakcie współpracy.

Z drugiej strony metoda ta może być także źródłem nietrafnych interpretacji, ponieważ zawsze oddaje ona przebieg co najmniej dwóch rodzajów procesów: przyjmowania perspektywy i interpretacji wypowiedzi. Z tego względu należy przede wszystkim w badaniach z użyciem metody w restrykcyjny sposób kontrolować koszty interpretacji leksykalnej, a wiec w praktyce kontrolować sposób opisu, wygląd i ułożenie bodźców (por. A. Dębska/ J. Rączaszek-Leonardi 2016). Oczywiście, rodzaj kontroli bodźców będzie zależał od rodzaju celów badawczych. Jeśli celem badania jest rozstrzygnięcie, w jakim stopniu typowe osoby dorosłe (lub inna grupa demograficzna) są egocentryczne w czasie konwersacji, wtedy należy zwrócić uwagę, by różnice między grupą kontrolną a eksperymentalną dotyczyły tylko różnicy w zakresie podzielanej perspektywy, a nie odnosiły się do wyglądu bodźców. Jeśli jednak celem badania jest określenie różnic miedzy dwoma grupami, na przykład porównanie jak efektywność w przyjmowaniu perspektywy rożni się w sytuacji, gdy rozmówca jest godny lub niegodny zaufania (zob. A. Dębska 2016, nieopublikowana praca doktorska), wtedy różnice miedzy warunkiem eksperymentalnym a kontrolnym można uznać za pomijalne, ponieważ występują one dla obu grup osób badanych. Trzecia grupa sytuacji dotyczy 
badan gdzie wpływ zarówno różnic w wyglądzie i opisie bodźców jak i różnicy perspektyw może mieć znaczenie dla wykonania zadania. Na przykład, gdy porównujemy wykonanie dwóch grup wiekowych dzieci pod kątem nasilenia egocentryzmu. J.J. Wangi in. (w druku) wykazała, ze złożoność językowa ma wpływ na wykonywania zadania B. Keysara i innych przez dzieci, zatem dodatkowym, niekontrolowanym czynnikiem może się stać koszt leksykalny rozwiązywania konfliktu odniesienia. Podobnie należałoby kontrolować taki koszt $\mathrm{w}$ przypadku badań porównawczych - międzykulturowych, w procesie tłumaczenia wyrażeń krytycznych i doboru bodźców.

Jeśli chce się całkowicie pominąć wpływ języka w badaniach nad przyjmowaniem perspektywy poznawczej można wykorzystać testy niewerbalne. Jednym z przykładowych jest test zaproponowany przez A. Quershi'ego i in. (2010). W tym zadaniu komputerowym badany ma określić, ile kropek w pokoju widzi awatar (cudza perspektywa) lub, ile kropek jest w pokoju (perspektywa osoby badanej). Awatar może widzieć albo taką samą ilość kropek co badany (warunek SPÓJNY) lub mniejszą ilość (warunek NIESPÓJNY). Na początku każdej próby wyświetla się informacja zgodnie z jaką perspektywą badany ma oszacować, ile jest kropek w pokoju (np. ON 2, co oznacza: „Czy prawdą jest, że awatar widzi dwie kropki?”). Następnie pojawia się widok pokoju, w którym stoi awatar i kropki na jednej lub dwóch ścianach pokoju (awatar nie może zobaczyć kropek na ścianie, do której jest odwrócony tyłem). W czasie $1500 \mathrm{~ms}$ badany musi zdecydować, czy informacja przedstawiona na początku jest prawdziwa czy fałszywa (czy awatar widzi 2 kropki, czy nie). W zadaniu mierzy się czas reakcji oraz poprawność odpowiedzi. Powstają zatem 4 warunki w schemacie 2x2: (PERSPEKTYWA: ja, on x SPÓJNOŚĆ: spójne, niespójne). Oryginalne badanie składa się łącznie ze 152 prób w 4 blokach.

W poprzednich badaniach wykazano, że badani najszybciej reagują, kiedy perspektywy awatara i ich są spójne, niezależnie od tego, czy mają ocenić perspektywę ludzika czy swoją. Kiedy perspektywy są niespójne badany popełnia dwa rodzaje błędów: błąd egocentryczny - kiedy wolniej przetwarza odpowiedź, bo musi zignorować swoją perspektywę a przyjąć perspektywę awatara - lub błąd allocentryczny - kiedy przetwarza odpowiedź wolniej, bo przetwarza perspektywę awatara, zamiast odpowiedzieć tylko na podstawie swojej własnej perspektywy. Tendencja do przetwarzania perspektywy awatara, mimo polecenia przetwarzania tylko własnego punktu widzenia, jest dowodem na spontaniczne przetwarzanie perspektywy wizualnej. Zaletą metody jest to, że może jednocześnie mierzyć procesy egocentryczne, jak i allocentryczne, oraz ich stopień na skali ilościowej (czas reakcji) bez wpływu procesów związanych z interpretacją i produkcją języka.

\section{Podsumowanie}

W pracy przedstawiono metodę badania przyjmowania perspektywy poznawczej drugiej osoby w czasie komunikacji językowej. Opisano szczegółowo sposób a także zakres stosowania metody. Zwrócono uwagę na zalety i problemy związane z jej użyciem w badaniach eksperymentalnych. 


\section{Bibliografia}

Abu-Akel, A./ S. Wood/ P. Hansen/ I. Apperly (2015), Perspective-taking abilities in the balance between autism tendencies and psychosis proneness, (w:) Royal Society Publishing B, 282, 1-8. (http://rspb.royalsocietypublishing.org /content /282/1808/20150563; pobrano 22.12.2016).

Allopenna, P.D/ J.S. Magnuson/ M.K. Tanenhaus (1998), Tracking the time course of spoken word recognition using eye movements: Evidence for continuous mapping models, (w:) Journal of Memory and Language, 38, 419-439.

Apperly, I.A./ D.J. Carroll/ D. Samson/ A. Qureshi/ G.W. Humphreys/ G. Moffatt (2010), Why are there limits on theory of mind use? Evidence from adults' ability to follow instructions from an ignorant speaker, (w:) Quarterly Journal of Experimental Psychology, 63 (6), 1201-1217.

Barr, D.J. (2008), Pragmatic expectations and linguistic evidence: listeners anticipate but do not integrate common ground, (w:) Cognition, 109 (1), 18-40.

Begeer, S./ B.F. Malle/ M.S. Nieuwland/ B. Keysar (2010), Using Theory of Mind to represent and take part in social interactions: Comparing individuals with highfunctioning autism and typically developing controls, (w:) European Journal of Developmental Psychology, 7, 104-122.

Birch, S.A.J./ P. Bloom (2007), The Curse of Knowledge in Reasoning About False Belief, (w:) Psychological Science, 18, 382-386.

Brown-Schmidt S. (2009), The role of executive function in perspective-taking during on-line language comprehension, (w:) Psychonomic Bulletin and Review, 16, 893900.

Brown-Schmidt, S./ J.E. Hanna (2011), Talking in another person's shoes: Incremental perspective-taking in language processing, (w:) Dialog and Discourse, 2, 11-33.

Clark, H.H./ C.R. Marshall (1978), Reference diaries, (w:) D.L. Waltz (red.), Theoretical Issues in Natural Language Processing 2 (University of Illinois at UrbanaChampaign, July 25-27, 1978). New York, 57-63.

Clark, H.H. (1992), Arenas of Language Use (Psychology. Linguistics. Computer Science). Chicago.

Clark, H.H. (1996), Using language. Cambridge.

Clark, H.H./ T.B. CARLSON (1981), Context for comprehension, (w:) J. Long/ A. Baddeley (red.), Attention and performance IX. Hillsdale, 313-330.

Dębska, A./ J. Rączaszek-Leonardi (w druku), What makes us more egocentric in communication? The role of referent features and individual differences. Discourse Processes.

Dębska, A./ T. Soluch/ S. Gajownik/ M. Denkiewicz/ J. Raczaszek-Leonardi (w przygotowaniu), Semantic and pragmatic costs of interpretation in dialgoue. The perspective-taking study.

Dębska, A. (2016), Rekonstruowanie wiedzy i perspektywy poznawczej drugiej osoby w procesie komunikacji. (Nieopublikowana praca doktorska).

Dumontheil, I./ O. Kuster/ I.A. Apperly/ S.J. Blakemore (2010), Taking perspective into account in a communication task, (w:) Neuroimage, 52 (4), 1574-1583. 
Duran, N.D./ R. Dale (2014), Perspective-taking in dialogue as self-organization under social constraints, (w:) New Ideas in Psychology, 32/ 1, 131-146.

(http://cognaction.org/rdmaterials/php.cv/pdfs/article/duran_dale_newideas_2013.p df; pobrano 04.03.2013).

Epley, N./ C.K. Morewedge/ B. Keysar (2004), Perspective Taking in Children and Adults: Equivalent Egocentrism but Differential Correction, (w:) Journal of Experimental Social Psychology, 40, 760-768.

German, T./ J.A. Hehman (2006), Representational and executive selection resources in "theory of mind: Evidence from compromised belief-desire reasoning in old age, (w:) Cognition, 101, 129-152.

Hanna, J.E./ M.K. Tanenhaus (2004), Pragmatic effects on reference resolution in a collaborative task: evidence from eye movements, (w:) Cognitive Science, 28, 105115.

Hanna, J.E./ M.K. Tanenhaus/ J.C. Trueswell (2003), The effects of common ground and perspective on domains of referential interpretation, (w:) Journal of Memory and Language, 49, 43-61.

Keysar, B./ D.J. Barr/ J.A. Balin/ J.S. Brauner (2000), Taking perspective in conversation: The role of mutual knowledge in comprehension (w:) Psychological Sciences, $11,32-38$.

Keysar, B./ D.J. Barr/ J.A. Balin/ T.S. Peak (1998), Definite reference and mutual knowledge: Process models of common ground in comprehension, (w:) Journal of Memory and Language, 39, 1-20.

Keysar B./ S. Lin/ D.J. Barr (2003), Limits on theory of mind use in adults, (w:) Cognition, $89,25-41$.

Kuhlen, A.K./ S.E. Brennan (2013), Language in dialogue: When confederates might be hazardous to your data, (w:) Psychonomic Bulletin \& Review, 20 (1), 54-72.

Lin, S./ B. Keysar/ N. Epley (2010), Reflexively mindblind: Using theory of mind to interpret behavior requires effortful attention, (w:) Journal of Experimental Social Psychology, 46, 551-556.

Mitchell, P./ E.J. Robinson/ J.E. Isaacs/ R.M. Nye (1996), Contamination in reasoning about false belief: An instance of realist bias in adults but not children, (w:) Cognition, 59, 1-21.

Qureshi, A./ I.A. Apperly/ D. Samson (2010), Executive function is necessary for perspective-selection, not Level-1 visual perspective-calculation: Evidence from a dual-task study of adults, (w:) Cognition, 117 (2), 230-236.

Rączaszek-Leonardi, J./ A. Dębska/ A. Sochanowicz (2014), Pooling the ground: understanding and coordination in collective sense making, (w:) Frontiers in Psychology, 5, 1233.

Santiesteban, I./ P. Shah/ S. White/ G. Bird/ C. Heyes (2015), Mentalizing or submentalizing in a communication task? Evidence from autism and a camera control, (w:) Psychon Bull Rev, 22 (3), 844-9.

Santiesteban, I./ M.J. Banissy/ C. Catmur/ G. Bird (2012), Enhancing social ability by stimulating right temporoparietal junction, (w:) Current Biology, 22/ 23. 
Spivey, M./ M.K. Tanenhaus/ K. Eberhard/ J. Sedivy (2002), Eye movements and spoken language comprehension: Effects of visual context on syntactic ambiguity resolution, (w:) Cognitive Psychology, 45, 447-481.

Shintel, H./ B. Keysar (2009), Less is more: A minimalist account of joint action in communication, (w:) Topics in Cognitive Science, 1, 260-273.

Symeonidou, I./ I. Dumontheil/ W.Y. Chow/ R. Breheny (2016), Development of online use of theory of mind in adolescence: an eye-tracking study, (w:) Journal of Experimental Child Psycholog,y 149, 81-97.

Tanenhaus, M.K./ M.J. Spivey-Knowlton/ K.M. Eberhard/ J.C. Sedivy (1995), Integration of visual and linguistic information in spoken language comprehension, (w:) Science, 268, 1632-1634.

Tanenhaus, M.K./ J.C. Trueswell (1995), Sentence comprehension, (w:) J. Miller, P. Eimas (red.), Speech, language, and communication (Handbook of cognition and perception). San Diego, 217-262.

Wang, J.J./ J.E. Cane/ H.J. Ferguson/ S. Frisson/ I.A. Apperly (2015), Why is it sometimes difficult to take account of a speaker's perspective? (Nieopublikowany manuskrypt).

Wang, J.J./ S. Frisson/ M. Ali/ I.A. Apperly (w druku), Language complexity modulates 8-and 10-year-olds' success at using their theory of mind abilities in a communication task, (w:) Journal of Experimental Child Psychology. 